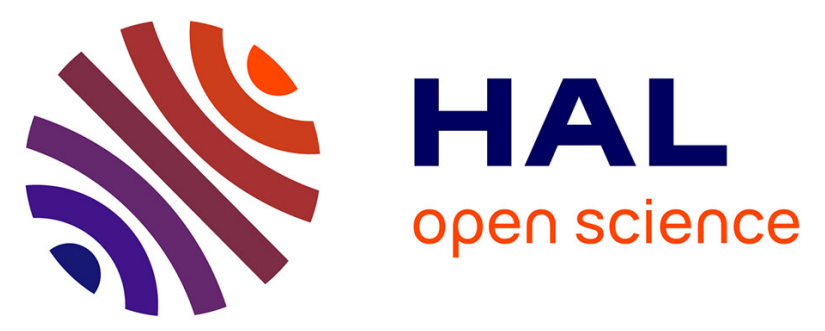

\title{
A High HIV DNA Level in PBMCs at Antiretroviral Treatment Interruption Predicts a Shorter Time to Treatment Resumption Independently of CD4 Nadir
}

Christophe Piketty, Laurence Weiss, Lambert Assoumou, Marianne Burgard, Aurelie Melard, Jean-Michel Ragnaud, Michele Bentata, Pierre Marie Girard, Christine Rouzioux, Dominique Costagliola

\section{To cite this version:}

Christophe Piketty, Laurence Weiss, Lambert Assoumou, Marianne Burgard, Aurelie Melard, et al.. A High HIV DNA Level in PBMCs at Antiretroviral Treatment Interruption Predicts a Shorter Time to Treatment Resumption Independently of CD4 Nadir. Journal of Medical Virology, 2010, 82 (11), pp.1819. 10.1002/jmv.21907 . hal-00577327

\section{HAL Id: hal-00577327 \\ https://hal.science/hal-00577327}

Submitted on 17 Mar 2011

HAL is a multi-disciplinary open access archive for the deposit and dissemination of scientific research documents, whether they are published or not. The documents may come from teaching and research institutions in France or abroad, or from public or private research centers.
L'archive ouverte pluridisciplinaire HAL, est destinée au dépôt et à la diffusion de documents scientifiques de niveau recherche, publiés ou non, émanant des établissements d'enseignement et de recherche français ou étrangers, des laboratoires publics ou privés. 


\section{A High HIV DNA Level in PBMCs at Antiretroviral Treatment Interruption Predicts a Shorter Time to Treatment Resumption Independently of CD4 Nadir}

\begin{tabular}{|c|c|}
\hline Journal: & Journal of Medical Virology \\
\hline Manuscript ID: & JMV-10-1755.R1 \\
\hline Wiley - Manuscript type: & Research Article \\
\hline $\begin{array}{r}\text { Date Submitted by the } \\
\text { Author: }\end{array}$ & 18-Jun-2010 \\
\hline Complete List of Authors: & $\begin{array}{l}\text { Piketty, Christophe; Service d'Immunologie Clinique, Hôpital } \\
\text { Européen Georges Pompidou, Paris } \\
\text { Weiss, Laurence } \\
\text { assoumou, lambert } \\
\text { Burgard, Marianne; Hop necker } \\
\text { melard, aurelie; Hop necker } \\
\text { ragnaud, jean-michel } \\
\text { bentata, michele } \\
\text { Girard, Pierre Marie; Universitary hospital, Infectious disease } \\
\text { Rouzioux, Christine; Hop necker } \\
\text { costagliola, dominique }\end{array}$ \\
\hline Keywords: & HIV, treatment interruption, HIV-DNA, CD4 nadir, CART \\
\hline
\end{tabular}

\section{S ScholarONE" \\ Manuscript Central}



Treatment Interruption Predicts a Shorter Time to

\section{Treatment Resumption, Independently of the CD4 Nadir}

4

5 Christophe Piketty ${ }^{1}$, Laurence Weiss ${ }^{1,2}$, Lambert Assoumou ${ }^{3,4}$,

6 Marianne Burgard $^{5}$, Aurélie Mélard ${ }^{5}$, Jean-Michel Ragnaud ${ }^{6}$,

7 Michele Bentata $^{7}$, Pierre-Marie Girard ${ }^{8}$, Christine Rouzioux ${ }^{2,5}$,

8 Dominique Costagliola ${ }^{3,49}$ and the ANRS 116 SALTO study

9 group

${ }^{1}$ AP-HP, Service d'Immunologie Clinique, Hôpital Européen Georges

12 Pompidou, Paris;

13 2Université Paris Descartes, Paris ;

$14{ }^{3}$ INSERM U 943, Paris F-75013, France

15 "UPMC Univ Paris 06, UMR S 943, Paris F-75013, France;

$16{ }^{5}$ AP-HP, Laboratoire de Virologie, Hôpital Necker, Paris,

$17{ }^{6}$ Service des Maladies Infectieuses, Hôpital Pellegrin, Bordeaux,

$18{ }^{7}$ AP-HP, Service de Médecine Interne, Hôpital Avicenne, Bobigny,

$19{ }^{8} \mathrm{AP}-\mathrm{HP}$, Service des Maladies Infectieuses, Hôpital Saint-Antoine, Paris ;

$20{ }^{9}$ AP-HP, Groupe hospitalier Pitié-Salpétrière, Service de Maladies Infectieuses

21 et Tropicales, Paris F-75013, France

22

23

Running head: CD4-guided treatment interruption 


\section{Corresponding author:}

2 Christophe Piketty, MD, PhD

3 Service d'Immunologie Clinique, Hôpital Européen Georges Pompidou,

420 Rue Leblanc

575908 Paris Cedex 15, France.

6 Phone: 33 (1) 560932 93; FAX: 33 (1) 560930 26;

$7 \quad$ E-mail: christophe.piketty@egp.aphp.fr

8

9

10 


\section{Abstract}

2

3 This study aimed to evaluate the safety of antiretroviral treatment interruption

4 (TI) in HIV-infected patients who started treatment based on earlier guidelines,

5 and to identify baseline factors predictive of the time to reach fixed criteria for

6 treatment resumption.

7 Prospective, open-label, multicentre trial. Patients were eligible if they had a

8 CD4 cell count $>350 / \mathrm{mm}^{3}$ and plasma HIV RNA $<50000$ copies/ml when they

9 first started antiretroviral therapy (ART); and if they had a CD4 count $>450 / \mathrm{mm}^{3}$ and stable plasma HIV RNA $<5000$ copies/mL for at least six months prior to enrolment. The criteria for ART resumption were a CD4 cell count $<300 / \mathrm{mm}^{3}$ and/or a CDC stage B or C event.

116 patients had received ART for a median of 5.3 years. The median CD4 cell count and plasma HIV RNA values at inclusion were $809 / \mathrm{mm}^{3}$ and $2.6 \mathrm{log}$ copies/mL, respectively. Median HIV DNA load at inclusion was $2.3 \log$ copies $/ 10^{6}$ PBMCs. Thirty-six months after $\mathrm{TI}, 63.9 \%$ of the patients had not yet reached the criteria for ART resumption, and $55.9 \%$ of patients had not resumed ART. In Cox multivariable analysis, a high HIV DNA level at TI, a low CD4 nadir, and pre-existing AIDS status were the only significant risk factors for reaching the criteria for ART resumption (hazards ratio: 2.15(1.02-4.53), 4.59(1.22-17.24) and 5.74(1.60-20.56), respectively).

Patients who started ART with a CD4 cell count above $350 / \mathrm{mm}^{3}$ were able to interrupt treatment for long periods without a high absolute risk of either AIDS or severe non-AIDS morbidity/mortality. A high PBMC HIV DNA level at treatment interruption was a strong predictor for more rapid treatment resumption. 
1 (ClinicalTrials.gov Identifier, NCT00118677)

2 Key words: HIV, treatment interruption, HIV-DNA, CD4 nadir, ART 


\section{Introduction}

2 Combined antiretroviral therapy (ART) increases CD4 cell numbers, reduces

3 plasma HIV RNA levels and improves patient survival [Hogg et al., 1998; Hogg

4 et al., 2001; Lee et al., 2001; Li et al., 1998; Mocroft et al., 2000; Murphy et al.,

5 2001; Palella et al., 1998; Palella et al., 2003]. However, efficacy can be

6 undermined by suboptimal adherence to treatment and by adverse effects.

7 Treatment interruption appears to be feasible and safe in patients with high CD4

8 cell counts, a high CD4 nadir, and long-term undetectable plasma HIV RNA, as

9 suggested by several small uncontrolled studies [Boschi et al., 2004; Fagard et

10 al., 2003; Fernandez Guerrero et al., 2005; Giuntini et al., 2005; Krolewiecki et

11 al., 2006; Maggiolo et al., 2004; Parish et al., 2002; Pellegrin et al., 2005;

12 Pogany et al., 2007; Ruiz et al., 2000; Skiest et al., 2004; Skiest et al., 2007;

13 Tarwater et al., 2003] and by two controlled trials [Ananworanich et al., 2006;

14 Maggiolo et al., 2008]. However, recent large randomized trials indicate that,

15 compared with patients who continue ART, unselected patients undergoing 16 treatment interruption experience significantly worse clinical outcomes, 17 including HIV disease progression and cardiovascular events [Danel et al., 18 2006; El-Sadr et al., 2006].

19 In view of the results of these latter studies, treatment interruptions are no 20 longer recommended. However, many patients are concerned with the toxicity 21 and potential long-term adverse effects of ART, and spontaneously stop taking 22 their treatment. Factors predictive of treatment resumption would therefore be 23 useful for clinicians managing such patients, but have not been studied 24 extensively. 
1 The aim of this study was to evaluate the safety of treatment interruption in 2 chronically HIV-infected patients who started ART based on earlier guidelines 3 and who had a high CD4 nadir. Factors potentially predictive of the length of 4 treatment interruption, and changes in metabolic parameters were also 5 examined.

6 


\section{Patients and Methods}

2

\section{$3 \quad$ Study design}

4 The ANRS 116 SALTO trial was a prospective, open-label, multicenter trial of

5 treatment interruption in patients who had started treatment early in the course

6 of HIV infection, based on contemporary guidelines, and who wished to

7 discontinue ART. The study protocol was approved by the ethics committee of

8 Pitié Salpétrière Hospital, Paris, France, and all the patients gave their written

9 informed consent before entering the study. The study conformed to the 10 International Conference on Harmonization guidelines for Good Clinical 11 Practices, and with the Helsinki Declaration.

\section{Study population}

14 The following patients were eligible: HIV-infected men and non pregnant women 15 at least 18 years of age; who had a CD4 cell count above $350 / \mathrm{mm}^{3}$ and plasma 16 HIV RNA below 50000 copies/ml (4.7 $\log _{10}$ copies/ml) at ART initiation; who 17 had been on a stable ART regimen (at least two drugs) for 6 months prior to 18 inclusion; who had had no more than one treatment failure; and who, at 19 baseline, had a CD4 cell count above $450 / \mathrm{mm}^{3}$ and stable plasma HIV RNA below 5000 copies $/ \mathrm{ml}$.

21 The exclusion criteria were chronic hepatitis B treated with lamivudine or 22 tenofovir disoproxil fumarate; acute opportunistic infections; and anticancer 23 chemotherapy or immunotherapy. 


\section{$1 \quad$ Assessment and monitoring}

2

3 Study design

4 ART was interrupted at enrolment in the study and the patients were monitored

5 for up to 36 months. Patients taking a non nucleoside reverse transcriptase

6 inhibitor were advised to discontinue it 7 days before their other antiretroviral 7 drugs.

8 The patients were evaluated at the screening visit (week -4$)$, then at day $0(\mathrm{TI})$,

9 week 2, months 1,2, 4 and 6, and every 3 months thereafter until month 36 .

10 Absolute numbers of CD4 T lymphocytes were determined by flow cytometry in

11 whole blood. The plasma HIV RNA level was determined with the techniques

12 routinely used in each participating center, all of which had a detection limit of

13400 genome copies/mL. Each patient's samples were all tested with the same

14 technique. The plasma HIV RNA level and the CD4 cell count were determined 15 at each study visit.

16 The HIV DNA level in peripheral blood mononuclear cells (PBMCs) was

17 measured in blood samples taken at day 0 and at months 6,12 and 18. PBMC 18 HIV-1 DNA was quantified by real-time PCR with amplification of the LTR gene, 19 using the 8E5 cell line as an external standard [Avettand-Fenoel et al., 2007; 20 Goujard et al., 2006; Rouzioux et al., 2005]. Briefly, PBMCs were separated by 21 Ficoll-Hypaque gradient centrifugation and aliquots were frozen until use. Total 22 DNA extracted from each aliquot of PBMCs was first quantified with the 23 Hoechst dye method (Pharmacia), $1 \mu \mathrm{g}$ of DNA being considered equivalent to $24 \sim 150000$ cells. This HIV-DNA PCR method quantifies total HIV-DNA (both 25 integrated and non integrated). Final results were expressed as the number or 
$1 \log _{10}$ number of HIV-1 DNA copies per $10^{6}$ PBMCs (quantification limit: 5

2 copies/PCR, i.e. 30 copies $/ 10^{6}$ PBMCs).

3 Frozen plasma samples were collected at months 1, 6, 12, 18 and 24. HIV

4 genotypic resistance mutations were studied before treatment resumption, as

5 described elsewhere [Mouroux et al., 2001].

6 Safety was assessed at each visit by means of an interview, a physical

7 examination, and collection of adverse events. Adverse events were coded with

8 the Medical Dictionary for Regulatory Activities (MedDRA) and their severity

9 was graded from 1 to 4 with the ANRS Adverse Event Grading Scale.

10 Lipodystrophy was scored clinically, and anthropometric measurements were

11 made (waist and hip circumference, waist/hip ratio, thigh circumference and

12 body mass index) on day 0 and at months 6,24 and 36 .

13 Total cholesterol, HDL cholesterol, LDL cholesterol and triglyceride serum

14 levels were measured after an overnight fast on day 0 and every 6 months 15 thereafter.

16 The criteria for ART resumption were a fall in the CD4 cell count to below $17300 / \mathrm{mm}^{3}$ in two consecutive samples collected 15 days apart, and/or the 18 occurrence of a stage B or C AIDS-defining event. Immunologic and virologic responses were assessed 1,3 and 6 months after ART resumption.

20

21 Statistical analysis

\section{Sample size}

23 To estimate the percentage of patients who did not reach the ART resumption

24 criteria 12 months after antiretroviral treatment interruption, with a precision of $2510 \%, 100$ patients needed to be enrolled. 


\section{Statistical Analysis}

3 The results are reported as proportions (and 95\% confidence intervals when

4 appropriate) for categorical variables, and as medians and interquartile ranges

5 for continuous variables. Changes in the CD4 cell count during treatment

6 interruption were analyzed by using mixed linear models, testing for changes in

7 the slopes during the interruption, with cut points chosen after visual inspection

8 of the median CD4 cell count at each time point. In these analyses, patients

9 resuming ART were censored at the time of treatment resumption. The primary

10 endpoint was the time to the first of two consecutive CD4 cell counts below

$11300 / \mathrm{mm}^{3}, 15$ days apart, or a CDC stage B or C AIDS-defining event. All events

12 were reviewed by the Data and Safety Monitoring Board. Patients who reached

13 the primary endpoint were analyzed as such even if they did not resume

14 treatment, while patients who resumed treatment without reaching the primary

15 endpoint were censored at time of treatment resumption in the intent-to-treat

16 analysis. In the analysis of observational data, all patients resuming therapy

17 were considered to have reached the primary endpoint. The percentage of

18 patients reaching the primary endpoint was determined using Kaplan-Meier

19 estimates. Factors associated with the occurrence of the primary endpoint were

20 analyzed with univariate and multivariable Cox proportional hazards models.

21 The following variables were tested: baseline age, gender, transmission group,

22 AIDS status, the CD4 cell nadir, the pre-ART CD4 cell count, the baseline CD4

23 cell count, pre-ART plasma HIV-1 RNA, baseline PMBC HIV DNA, the duration

24 of ART at treatment interruption, and the use of dual- or triple-drug therapy.

25 Akaike's criteria were used to determine whether continuous variables were 
1 best modelled as continuous variables, or after log transformation, or as three2 class categorical variables based on the terciles. Based on the results of these 3 analyses, the baseline CD4 cell count and the baseline HIV DNA level, 4 expressed in $\log _{10}$ values, were modelled as three-class variables, and the CD4 5 cell nadir and the pre-ART CD4 cell count expressed in $\log _{2}$ were modelled as 6 continuous variables in the final model. Variables with $p$ values below 0.05 in 7 univariate analysis were entered in the Cox multivariable model by using a 8 backward procedure.

9 Changes in lipodystrophy and metabolic parameters were tested for 10 significance with Wilcoxon's paired test. The SPSS software package version 1115.0 for Windows (SPSS Inc., Illinois, Chicago) and the SAS software package 12 version 9.1 (SAS institute, Cary, NC, USA) were used for all analyses. 


\section{Results}

\section{Study population}

4 One hundred and sixteen patients (37\% women) were enrolled at 21 sites

5 between January 2003 and March 2004. Baseline characteristics of the study

6 population are shown in Table 1. Follow-up during treatment interruption lasted

7 a total of 270.2 person-years. Three patients had had AIDS-defining events

8 prior to enrolment (pulmonary tuberculosis, esophageal candidiasis, cutaneous

9 Kaposi's sarcoma). The interrupted treatments comprised a protease inhibitor10 based regimen in $16 \%$ of cases, a non-nucleoside analogue regimen in $35 \%$ of 11 cases, a triple nucleoside analogue regimen in $34 \%$ of cases (Trizivir in $17 \%$ of 12 cases), a dual nucleoside analogue regimen in $14 \%$ of cases, and a non 13 nucleoside analogue plus a protease inhibitor in $1 \%$ of cases. The median (IQR) 14 CD4 cell count at inclusion was $806 / \mathrm{mm}^{3}(676-940)$ and the median CD4 15 nadir was $381 / \mathrm{mm}^{3}(341-490)$. Only $11 \%$ of the patients had a CD4 nadir 16 below $300 / \mathrm{mm}^{3}$. The median pre-ART plasma HIV RNA level was $4.2 \log _{10}$ 17 copies/mL (3.8 - 4.5). Ninety-one percent of the patients had a plasma HIV 18 RNA level below 400 copies at inclusion. The median baseline HIV DNA value 19 was 2.3 log copies per million PBMCs $(1.9-2.8)$.

\section{Patient disposition}

22 Four patients were lost to follow-up, at months 17, 24 (2 patients) and 27. Four 23 women left the study because they became pregnant, at months 2, 21, 24 and 24 32. One patient died, of a ruptured cerebral aneurysm at month 21. 
2 Dynamics of CD4+ T cell count, plasma HIV-RNA and PBMC

$3 \quad$ HIV-DNA values after treatment interruption

4 Changes in the median CD4 cell count after treatment interruption are shown in

5 Figure 1a. The CD4 cell curve comprised three distinct slopes: a first steep 6 decline $(-127.2 \pm 21.4$ cells $)$ during the first month, then a slower decline $(-15.4$

$7 \pm 2.2$ cells/month) between month 1 and month 12 , and a very slow decline (-

$83.1 \pm 0.8$ cells/month) between month 12 and month 36 . The median CD4 cell

9 counts at months 12,24 and 36 were respectively $497 / \mathrm{mm}^{3}$ (376 - 626), $10479 / \mathrm{mm}^{3}(394-628)$ and $455 / \mathrm{mm}^{3}(356-587)$.

11 Changes in plasma HIV RNA load after treatment interruption are shown in 12 Figure 1b. After a rapid increase from 2.6 to $4.0 \log _{10}$ copies per $\mathrm{ml}$ during the 13 first month, the median plasma HIV RNA level stabilized. Median plasma HIV 14 RNA values at months 12,24 and 36 were respectively $4.1 \log _{10}$ copies/mL (3.6 15 - 4.4), $4.1 \log _{10}$ copies/mL $\left(3.7\right.$ - 4.5) and $4.3 \log _{10}$ copies/mL (3.7 - 4.6). 16 Respectively $5 \%, 6 \%$ and $2 \%$ of patients still had plasma HIV RNA values 17 below 400 copies $/ \mathrm{mL}$ at months 12,24 and 36 of treatment interruption. Median 18 PBMC HIV DNA load in these patients at baseline and month 6 were 19 respectively $1.0(1.0-1.4)$ and $2.2(1.8-2.4) \log _{10}$ per million PBMCs.

20 Changes in HIV DNA load during the first 18 months of the study are shown in 21 Figure 1c. The HIV DNA level increased from $2.3(1.9-2.8)$ at baseline to 3.1 $22(2.7-3.4)$ at 18 months.

24 Incidence of the primary endpoint 
1 Within 36 months after treatment interruption, 23 patients $(27.0 \%)$ reached a

2 CD4 cell count below $300 / \mathrm{mm}^{3}$ and 20 of them (22.8\%) resumed therapy.

3 Another nine patients (12.4\%) resumed therapy because of CDC stage B or C

4 events, and 20 patients (20.0\%) resumed therapy for other reasons (mainly at

5 the patient's request).

6 The nine CDC stage B/C events consisted of severe thrombocytopenia (2 7 cases), oral hairy leukoplakia (3 patients), oral candidiasis (2 patients) and

8 cutaneous Kaposi's sarcoma (2 patients). One of the two patients who

9 developed cutaneous Kaposi's sarcoma during treatment interruption had 10 already had a first episode prior to enrolment in the study. The CD4 cell counts 11 of these two patients at the onset of Kaposi's sarcoma during treatment 12 interruption were $648 / \mathrm{mm}^{3}$ and $364 / \mathrm{mm}^{3}$. No AIDS-defining events occurred 13 during the first 12 months of treatment interruption.

14 In the intent-to-treat analysis the proportions of patients who did not meet the 15 criteria for ART resumption at months 12,24 and 36 were respectively $97.3 \%$ 16 (95\% Cl: $92.5-99.1), 86.5 \%(78.5-91.8)$, and $63.9 \%(52.9-73.6)$. The 17 proportions of patient who had not resumed ART at months 12, 24 and 36 18 (observational data) were respectively $92.2 \%(85.8$ - 95.8), 75.3\% (66.5 19 82.4), and 55.9\% (46.1-65.3).

20

21 Factors predictive of reaching the primary endpoint

22 The results of univariate and multivariable Cox proportional hazards models are 23 shown in Table 2. In univariate analyses, HIV DNA load above $2.56 \log _{10}$ per 24 million PBMCs, a low CD4 nadir, the pre-ART CD4 cell count, the baseline CD4 
1 cell count, and AIDS status at baseline were significantly associated with the

2 time taken to reach the primary endpoint.

3 In multivariable analyses, HIV DNA load above the upper tercile of 2.56

$4 \log _{10} / 10^{6}$ PBMCs (hazards ratio, $H R=2.15$ ), a low CD4 nadir (HR=4.59 per $50 \%$

5 reduction in the $\mathrm{CD} 4$ nadir) and pre-existing AIDS status $(\mathrm{HR}=5.74)$ were all

6 predictive of a shorter time to the first of two CD4 cell counts below $300 / \mathrm{mm}^{3}$,

715 days apart, or to a CDC stage B or C event. The Kaplan-Meier curves

8 representing the time to the primary endpoint are shown in Figure 2 according

9 to HIV DNA load (above or below $2.56 \log _{10}$ per million PBMCs) adjusted for the 10 CD4 nadir.

12 Severe non AIDS-defining morbidity

13 Four cardiovascular events occurred during follow-up, including two cases of 14 coronary artery disease (CD4 cell counts at diagnosis: 337 and 448), one stroke 15 (CD4=346), and one ruptured cerebral aneurysm ( $C D 4=559)$; the incidence of 16 cardiovascular events was $1.5 / 100$ person-years (95\% Cl: $0.6-3.2)$.

17 No cases of renal or hepatic failure and no non AIDS-related malignancies 18 occurred during follow-up.

\section{Changes in lipodystrophy and metabolic parameters}

21 Changes in anthropometric measurements, lipodystrophy scores and metabolic 22 parameters between day 0 and the last follow-up visit during treatment 23 interruption are shown in Table 3. No significant change in anthropometric 24 values occurred, but the proportion of patients with either lipoatrophy or 
1 lipohypertrophy fell significantly (42\% versus $23 \%, p<0.001$; and $43 \%$ versus $216 \%, \mathrm{p}<0.001$, respectively).

3 The median changes in the total serum cholesterol level, the serum HDL

4 cholesterol level, and the serum LDL cholesterol level from baseline to the last 5 follow-up visit off treatment were respectively $-0.35 \mathrm{mmol} / \mathrm{I}(\mathrm{IQR}-0.99,0.08)(\mathrm{p}$ $6<0.001),-0.11 \mathrm{mmol} / \mathrm{l}(-0.33,0.05)(\mathrm{p}<0.001)$ and $-0.25 \mathrm{mmol} / \mathrm{l}(-0.78,0.26)(\mathrm{p}$ $7=0.001)$. Serum glucose and triglycerides levels did not change significantly 8 during treatment interruption.

9

\section{Treatment resumption}

11 Of the 47 patients who resumed therapy during the 36 months of follow-up, 31 12 patients (66\%) were prescribed a regimen different from that received prior to 13 enrolment. The median CD4 cell count was $345 / \mathrm{mm}^{3}(256-446)$ at resumption, 14 and $475 / \mathrm{mm}^{3}(388-587)$ six months later. The median plasma HIV RNA level 15 was 26470 copies/mL $(4790-81430)$ at resumption, and 39 patients $(81 \%)$ had 16 plasma HIV RNA levels below 400 copies/mL six months later. Genotypic 17 mutations conferring resistance to NRTIs and NNRTIs were identified in all 8 18 patients (19\%) who had plasma HIV RNA levels above 400 copies/mL six 19 months after resumption. The baseline profile was not available in three of 20 these patients. Only one of the remaining five patients acquired resistance to a 21 new drug (3TC). At treatment interruption, 6 of these 8 patients had plasma HIV 22 RNA values below 400 copies $/ \mathrm{mL}$. The ART regimens were subsequently 23 optimized, and plasma HIV RNA became undetectable ( $<400$ copies $/ \mathrm{mL}$ ) after a 24 further 6 months in 7 of the 8 patients.

25 No B or $\mathrm{C}$ events were diagnosed after treatment resumption. 

cell counts were above $350 / \mathrm{mm} 3$, had already had an episode of Kaposi's sarcoma prior to inclusion. Both these events occurred after one year off reported an incidence rate of $0.8 / 100 \mathrm{P}-\mathrm{Y}$ in such patients [Guiguet et al., 2008].

Our findings are in keeping with those of other studies of treatment interruption

\section{Discussion}

2 This study indicates that treatment interruption in selected patients with a high

3 CD4 cell nadir is associated with a low rate of HIV disease progression after 36

4 months. Only $36 \%$ of the patients met the criteria for treatment resumption

5 during the 36 months of follow-up, namely a CD4 cell count below $300 / \mathrm{mm}^{3}$ or a

6 CDC stage B or C event. Only two CDC grade C clinical events (two cases of

7 cutaneous Kaposi's sarcoma) occurred during the 36 months of follow-up. It

should be noted that patients with AIDS were eligible for this study. One of the

9 two patients who developed Kaposi's sarcoma during follow-up, when their CD4 treatment, and the incidence was $0.7 / 100 \mathrm{P}-\mathrm{Y}$. This is within the range of incidence rates observed elsewhere in antiretroviral-naive patients with CD4 cell counts $>350 / \mathrm{mm}^{3}$ [Guiguet et al., 2008; Phillips et al., 2007]. Guiguet et al. in similar populations [Ananworanich et al., 2006; Boschi et al., 2004; Maggiolo et al., 2008; Mata et al., 2005; Mussini et al., 2005; Pogany et al., 2007; Skiest et al., 2004; Skiest et al., 2007; Wit et al., 2005]. Among the 284 patients included in the treatment interruption arm of the Staccato trial [Ananworanich et al., 2006], only minor HIV-related signs and symptoms were observed, with no AIDS-defining events or AIDS-related deaths. In a recent trial [Maggiolo et al., 2008], 329 patients with a CD4 cell nadir above $200 / \mathrm{mm}^{3}$ and a CD4 cell count above $700 / \mathrm{mm}^{3}$ at inclusion were randomized to continue their ongoing antiretroviral treatment or to discontinue it until their CD4 cell count fell to 
$1350 / \mathrm{mm}^{3}$. During $689 \mathrm{P}-\mathrm{Y}$ of follow-up, only one AIDS-defining event occurred

2 in the STI arm and none in the control arm, while eight cases of pneumonia

3 occurred in the STI arm, compared to one in the control arm. However, recent

4 large studies have shown a higher rate of clinical events in patients undergoing

5 CD4-guided treatment interruption than in patients who continue on treatment

6 [Danel et al., 2006; El-Sadr et al., 2006]. These studies did not exclude patients

7 with AIDS or HIV-related disorders, and included patients with different degrees

8 of immune impairment and low CD4 cell nadirs. One study in which there was a

9 high rate of events (mainly bacterial infections) during treatment interruption

10 involved patients in Africa, where the background rate of opportunistic infections

11 may be higher [Danel et al., 2006].

12 Among the patients enrolled in the SMART trial, opportunistic infections and 13 deaths were significantly more frequent in the "drug conservation" arm, in which

14 ART initiation or resumption was deferred until the CD4 cell count fell to $15250 / \mathrm{mm}^{3}$ ), than in the continuous ART arm. Even in the subgroup of patients 16 whose last CD4 cell count was above $350 / \mathrm{mm}^{3}$, the incidence of AIDS-related 17 events in the "drug conservation" arm was 1.28 per 100 person-years [Lundgren 18 et al., 2008], a rate similar to that found in the present study (0.7/100 P-Y;IQR $190.2-2.0)$. However, clinical events were infrequent in our study, in which the 20 patients had started first-line antiretroviral therapy with CD4 cell counts above $21350 / \mathrm{mm}^{3}$. This further suggests that lengthy treatment interruption is less risky 22 in AIDS-free patients with a high CD4 cell nadir.

23 The SMART study highlighted an increased risk of cardiovascular events during 24 treatment interruption [El-Sadr et al., 2006]. A slight increase in cardiovascular 25 events was observed in the "drug conservation" arm of the SMART study, with 
1 an incidence of $1.3 / 100 \mathrm{P}-\mathrm{Y}$, compared to $1.5 / 100 \mathrm{P}-\mathrm{Y}$ in this study. As HIV

2 replication induces immune activation, plasma HIV RNA rebound during

3 treatment interruption might lead to inflammation and endothelial dysfunction,

4 thereby increasing the risk of cardiovascular events [Blum et al., 2005; Solages

5 et al., 2006; Tebas et al., 2008].

6 As also observed elsewhere [Hatano et al., 2000], a significant improvement of

7 lipodystrophy and lipid abnormalities was observed during treatment

8 interruption. However, changes in lipodystrophy were assessed with an

9 unvalidated clinical score, and no significant change in anthropometric values 10 was observed during treatment interruption.

11 As reported previously by others, this study showed a rapid initial CD4 cell 12 decline after ART interruption, followed by a more gradual loss during the first 13 months (accompanied by a rapid increase in plasma HIV RNA), and then by 14 CD4 cell count and plasma HIV RNA load stabilization [Boschi et al., 2004; 15 Fagard et al., 2005; Maggiolo et al., 2004; Skiest et al., 2007; Tarwater et al., 16 2003; Tebas et al., 2002; Thiebaut et al., 2005; Wit et al., 2005]. The present 17 study showed an increase in HIV DNA levels after treatment interruption, 18 indicative of gradual replenishment of cellular reservoirs.

19 In Cox proportional hazards multivariable analyses, baseline factors predictive 20 of outcome 36 months after treatment interruption were PBMC HIV DNA load 21 above the upper tercile $\left(2.56 \log _{10}\right.$ copies $\left./ \mathrm{ml}\right)$, the CD4 nadir, and AIDS status. 22 It is commonly reported that the higher the CD4 cell nadir, the smaller the fall in 23 the CD4 cell count and the longer the duration of treatment interruption [Boschi 24 et al., 2004; Fernandez Guerrero et al., 2005; Giuntini et al., 2005; Maggiolo et 25 al., 2004; Mata et al., 2005; Mussini et al., 2005; Poulton et al., 2003; Skiest et 
1 al., 2004; Skiest et al., 2007; Tarwater et al., 2003; Thiebaut et al., 2005]. As

2 also found in some other studies, the pre-ART plasma HIV RNA level was not

3 predictive of the duration of treatment interruption in this study [Maggiolo et al.,

4 2004; Tebas et al., 2002]. Interestingly, the PBMC HIV DNA levels above 2.56

$5 \log _{10}$ copies $/ 10^{6}$ PBMCs were an independent predictor of a shorter time to

6 treatment resumption. PBMC HIV DNA load was also found to be a significant

7 predictor of treatment resumption in a pilot study involving 62 patients who

8 stopped their ongoing antiretroviral treatment [Sarmati et al., 2009]. The HIV-

9 DNA level provides an estimate of the proportion of circulating HIV-infected 10 cells and reflects the size of the viral reservoir. Central and transitional memory

11 CD4+ T cells contribute to the HIV reservoir, the size of which correlates with 12 the nadir CD4 cell count [Chomont et al., 2009]. PBMC HIV-1 DNA load shortly 13 after infection is predictive of disease progression, independently of the plasma 14 HIV-RNA level and the CD4 cell count [Goujard et al., 2006; Rouzioux et al., 15 2005]. The HIV reservoir is established soon after infection, and the degree to 16 which it is diminished by ART, whether initiated during the acute or chronic 17 phase of infection, is variable [Ngo-Giang-Huong et al., 2001; Strain et al., 2003]. While all patients in this study had low or undetectable plasma HIV-RNA at inclusion, their HIV-DNA levels varied over a broad range and were therefore informative. These results suggest that the larger the viral reservoir at the time 21 of treatment interruption, the less time the patient can remain off treatment. In 22 other words, a high level of HIV-DNA was indicative of a risk of progression in case of treatment interruption, whatever the prior duration of ART.

24 Following the results of the SMART trial, treatment interruptions are not 25 currently recommended in HIV-infected patient management guidelines 
1 [Hammer et al., 2008; Yeni, 2008]. In current practice, the number of patients 2 who stop taking ART, for whatever reason, has fallen since the results of the 3 SMART trial were first reported in January 2006, but still represented $5.7 \%$ of 4 patients monitored in 2007 [Yeni, 2008]. Thus, it remains important to estimate 5 the risk of AIDS and severe non-AIDS morbidity/mortality during treatment 6 interruption, and to identify factors associated with the duration of interruption.

7 The results of this study indicate that patients with a history of AIDS-defining 8 events should not interrupt their treatment. In addition to a low CD4 nadir, a 9 high PBMC HIV DNA level at time of treatment interruption is a strong predictor 10 of more rapid treatment resumption, contrary to the pre-therapy plasma HIV-1 11 RNA level. 


\section{Acknowledgments}

\section{Sponsorship:}

3 This work was supported by Agence Nationale de Recherches sur le SIDA

4 (ANRS)

5 The ANRS 116 study group:

6 Hôpital Avicenne, Bobigny (M. Bentata); Hôpital Saint Antoine, Paris (P-M 7 Girard, J-L Meynard ); Hôpital Pitié Salpétrière, Paris (C. Katlama, R. Tubiana, 8 A. Simon); Hôpital Bicêtre (J-F Delfraissy, C. Gougard); Hôpital Henri Mondor, 9 Creteil (Y. Levy); Hôpital Tenon, Paris (G. Pialoux); Hôpital Necker, Paris (J-P 10 Viard); Hôpital Saint Jacques, Besançon (B. Hoen); Hôpital Bichat, Paris (P. 11 Yeni, R. Landman); Hôpital Sainte Marguerite, Marseille (JA. Gastaut, I. Poizot12 Martin); Hôpital Pellegrin, Bordeaux (JM Ragnaut); Hôpital Saint Jacques, 13 Bordeaux (P. Morlat); Hôpital Brabois, Nancy (T. May); CHU de Caen (C. 14 Bazin); CHU Strasbourg (JM. Lang); Hôpital Purpan, Toulouse (P. Massip); 15 Hôpital de l'Archet, Nice (JP. Cassuto); Hôpital Edouard Herriot, Lyon; Hôpital 16 Bretonneau, Tours (P. Choutet).

17 ANRS 116 SALTO Scientific committee:

18 C. Piketty, L. Weiss, D. Costagliola, C. Rouzioux, M. Burgard, C. Goujard, J-P 19 Viard, Y. Levy, G. Pialoux, J-L Meynard, S. Bachir Cherif, L. Assoumou, and 20 MJ. Commoy

21 ANRS 116 SALTO DSMB:

22 JL. Pellegrin, C. Fagard, L. Morand-Joubert, and J. Gilquin 23 


\section{References}

Ananworanich J, Gayet-Ageron A, Le Braz M, Prasithsirikul W, Chetchotisakd P, Kiertiburanakul S, Munsakul W, Raksakulkarn P, Tansuphasawasdikul S, Sirivichayakul S, Cavassini M, Karrer U, Genne D, Nuesch R, Vernazza P, Bernasconi E, Leduc D, Satchell C, Yerly S, Perrin L, Hill A, Perneger T, Phanuphak P, Furrer H, Cooper D, Ruxrungtham K, Hirschel B. 2006. CD4guided scheduled treatment interruptions compared with continuous therapy for patients infected with HIV-1: results of the Staccato randomised trial. Lancet 368(9534):459-465.

Avettand-Fenoel V, Mahlaoui N, Chaix ML, Milliancourt C, Burgard M, CavazzanaCalvo M, Rouzioux C, Blanche S. 2007. Failure of bone marrow transplantation to eradicate HIV reservoir despite efficient HAART. Aids 21(6):776-777.

Blum A, Hadas V, Burke M, Yust I, Kessler A. 2005. Viral load of the human immunodeficiency virus could be an independent risk factor for endothelial dysfunction. Clin Cardiol 28(3):149-153.

Boschi A, Tinelli C, Ortolani P, Moscatelli G, Morigi G, Arlotti M. 2004. CD4+ cell-countguided treatment interruptions in chronic HIV-infected patients with good response to highly active antiretroviral therapy. Aids 18(18):2381-2389.

Chomont N, El-Far M, Ancuta P, Trautmann L, Procopio FA, Yassine-Diab B, Boucher G, Boulassel MR, Ghattas G, Brenchley JM, Schacker TW, Hill BJ, Douek DC, Routy JP, Haddad EK, Sekaly RP. 2009. HIV reservoir size and persistence are driven by $T$ cell survival and homeostatic proliferation. Nat Med 15(8):893-900.

Danel C, Moh R, Minga A, Anzian A, Ba-Gomis O, Kanga C, Nzunetu G, Gabillard D, Rouet F, Sorho S, Chaix ML, Eholie S, Menan H, Sauvageot D, Bissagnene E, Salamon R, Anglaret X. 2006. CD4-guided structured antiretroviral treatment interruption strategy in HIV-infected adults in west Africa (Trivacan ANRS 1269 trial): a randomised trial. Lancet 367(9527):1981-1989.

El-Sadr WM, Lundgren JD, Neaton JD, Gordin F, Abrams D, Arduino RC, Babiker A, Burman W, Clumeck N, Cohen CJ, Cohn D, Cooper D, Darbyshire J, Emery S, Fatkenheuer G, Gazzard B, Grund B, Hoy J, Klingman K, Losso M, Markowitz N, Neuhaus J, Phillips A, Rappoport C. 2006. CD4+ count-guided interruption of antiretroviral treatment. N Engl J Med 355(22):2283-2296.

Fagard C, Bandelier CY, Ananworanich J, Le Braz M, Gunthard H, Perneger T, Garcia F, Hirschel B. 2005. Biphasic decline of CD4 cell count during scheduled treatment interruptions. Aids 19(4):439-441.

Fagard C, Oxenius A, Gunthard H, Garcia F, Le Braz M, Mestre G, Battegay M, Furrer $H$, Vernazza $P$, Bernasconi E, Telenti A, Weber R, Leduc D, Yerly S, Price D, Dawson SJ, Klimkait T, Perneger TV, McLean A, Clotet B, Gatell JM, Perrin L, Plana M, Phillips R, Hirschel B. 2003. A prospective trial of structured treatment interruptions in human immunodeficiency virus infection. Arch Intern Med 163(10):1220-1226.

Fernandez Guerrero ML, Rivas P, Molina M, Garcia R, De Gorgolas M. 2005. Longterm follow-up of asymptomatic HIV-infected patients who discontinued antiretroviral therapy. Clin Infect Dis 41(3):390-394.

Giuntini R, Martinelli C, Ambu S, Bartolozzi D, Farese A, Boddi V, Leoncini F. 2005. Prolonged treatment interruption in chronic HIV infection: a new strategy? Aids 19(2):209-211.

Goujard C, Bonarek M, Meyer L, Bonnet F, Chaix ML, Deveau C, Sinet M, Galimand J, Delfraissy JF, Venet A, Rouzioux C, Morlat P. 2006. CD4 cell count and HIV DNA level are independent predictors of disease progression after primary HIV type 1 infection in untreated patients. Clin Infect Dis 42(5):709-715. 
Guiguet M, Porter K, Phillips A, Costagliola D, Babiker A. 2008. Clinical Progression Rates by CD4 Cell Category Before and After the Initiation of Combination Antiretroviral Therapy (cART). The Open AIDS Journal 2:3-9.

Hammer SM, Eron JJ, Jr., Reiss P, Schooley RT, Thompson MA, Walmsley S, Cahn P, Fischl MA, Gatell JM, Hirsch MS, Jacobsen DM, Montaner JS, Richman DD, Yeni PG, Volberding PA. 2008. Antiretroviral treatment of adult HIV infection: 2008 recommendations of the International AIDS Society-USA panel. Jama 300(5):555-570.

Hatano H, Miller KD, Yoder CP, Yanovski JA, Sebring NG, Jones EC, Davey RT, Jr. 2000. Metabolic and anthropometric consequences of interruption of highly active antiretroviral therapy. Aids 14(13):1935-1942.

Hogg RS, Heath KV, Yip B, Craib KJ, O'Shaughnessy MV, Schechter MT, Montaner JS. 1998. Improved survival among HIV-infected individuals following initiation of antiretroviral therapy. Jama 279(6):450-454.

Hogg RS, Yip B, Chan KJ, Wood E, Craib KJ, O'Shaughnessy MV, Montaner JS. 2001. Rates of disease progression by baseline CD4 cell count and viral load after initiating triple-drug therapy. Jama 286(20):2568-2577.

Krolewiecki AJ, Zala C, Vanzulli C, Perez H, lannella Mdel C, Bouzas MB, Gun A, Valiente J, Cassetti I, Cahn P. 2006. Safe treatment interruptions in patients with nadir CD4 counts of more than 350 cells/microL: a randomized trial. J Acquir Immune Defic Syndr 41(4):425-429.

Lee LM, Karon JM, Selik R, Neal JJ, Fleming PL. 2001. Survival after AIDS diagnosis in adolescents and adults during the treatment era, United States, 1984-1997. Jama 285(10):1308-1315.

Li TS, Tubiana R, Katlama C, Calvez V, Ait Mohand H, Autran B. 1998. Long lasting recovery in CD4 T-cell function and viral-load reduction after highly active antiretroviral therapy in advanced HIV-1 disease. Lancet 351:1682-1686.

Lundgren JD, Babiker A, El-Sadr W, Emery S, Grund B, Neaton JD, Neuhaus J, Phillips AN. 2008. Inferior clinical outcome of the CD4+ cell count-guided antiretroviral treatment interruption strategy in the SMART study: role of CD4+ Cell counts and HIV RNA levels during follow-up. J Infect Dis 197(8):11451155.

Maggiolo F, Airoldi M, Callegaro A, Martinelli C, Dolara A, Bini T, Gregis G, Quinzan G, Ripamonti D, Ravasio V, Suter F. 2008. CD4 cell-guided scheduled treatment interruptions in HIV-infected patients with sustained immunologic response to HAART. Aids 24:24.

Maggiolo F, Ripamonti D, Gregis G, Quinzan G, Callegaro A, Suter F. 2004. Effect of prolonged discontinuation of successful antiretroviral therapy on CD4 T cells: a controlled, prospective trial. Aids 18(3):439-446.

Mata RC, Viciana P, de Alarcon A, Lopez-Cortes LF, Gomez-Vera J, Trastoy M, Cisneros JM. 2005. Discontinuation of antiretroviral therapy in patients with chronic HIV infection: clinical, virologic, and immunologic consequences. AIDS Patient Care STDS 19(9):550-562.

Mocroft A, Katlama C, Johnson AM, Pradier C, Antunes F, Mulcahy F, Chiesi A, Phillips AN, Kirk O, Lundgren JD. 2000. AIDS across Europe, 1994-98: the EuroSIDA study. Lancet 356(9226):291-296.

Mouroux M, Descamps D, Izopet J, Yvon A, Delaugerre C, Matheron S, Coutellier A, Valantin MA, Bonmarchand M, Agut $\mathrm{H}$, Massip P, Costagliola D, Katlama C, Brun-Vezinet F, Calvez V. 2001. Low-rate emergence of thymidine analogue mutations and multi-drug resistance mutations in the HIV-1 reverse transcriptase gene in therapy-naive patients receiving stavudine plus lamivudine combination therapy. Antivir Ther 6(3):179-183.

Murphy EL, Collier AC, Kalish LA, Assmann SF, Para MF, Flanigan TP, Kumar PN, Mintz L, Wallach FR, Nemo GJ. 2001. Highly active antiretroviral therapy 
decreases mortality and morbidity in patients with advanced HIV disease. Ann Intern Med 135(1):17-26.

Mussini C, Bedini A, Borghi V, Guaraldi G, Esposito R, Barchi E, Enilia R, Cozzi-Lepri A, Philips AN, Ortolani P, Bratt G, Eriksson LE, Sighinolfi L, Cossarizza A, d'Arminio Monforte A, De Luca A, Di Giambenedetto S, Antinori A. 2005. CD4 cell-monitored treatment interruption in patients with a CD4 cell count $>500 \mathrm{x}$ 106 cells/l. Aids 19(3):287-294.

Ngo-Giang-Huong N, Deveau C, Da Silva I, Pellegrin I, Venet A, Harzic M, Sinet M, Delfraissy JF, Meyer L, Goujard C, Rouzioux C. 2001. Proviral HIV-1 DNA in subjects followed since primary HIV-1 infection who suppress plasma viral load after one year of highly active antiretroviral therapy. Aids 15(6):665-673.

Palella FJ, Jr., Delaney KM, Moorman AC, Loveless MO, Fuhrer J, Satten GA, Aschman DJ, Holmberg SD. 1998. Declining morbidity and mortality among patients with advanced human immunodeficiency virus infection. New England Journal of Medicine 338(13):853-860.

Palella FJ, Jr., Deloria-Knoll M, Chmiel JS, Moorman AC, Wood KC, Greenberg AE, Holmberg SD. 2003. Survival benefit of initiating antiretroviral therapy in HIVinfected persons in different CD4+ cell strata. Ann Intern Med 138(8):620-626.

Parish MA, Tarwater P, Lu M, Raines C, Gallant JE. Prolonged treatment interruption after immunologic response to HAART; 2002; Barcelona, Spain. $p$ abstract ThOrB1439.

Pellegrin I, Thiebaut R, Blanco P, Viallard JF, Schrive MH, Merel P, Chene G, Fleury H, Moreau JF, Pellegrin JL. 2005. Can highly active antiretroviral therapy be interrupted in patients with sustained moderate HIV RNA and > 400 CD4+ cells/microl? Impact on immunovirological parameters. J Med Virol 77(2):164172.

Phillips AN, Gazzard B, Gilson R, Easterbrook P, Johnson M, Walsh J, Leen C, Fisher M, Orkin C, Anderson J, Pillay D, Delpech V, Sabin C, Schwenk A, Dunn D, Gompels M, Hill T, Porter K, Babiker A. 2007. Rate of AIDS diseases or death in HIV-infected antiretroviral therapy-naive individuals with high CD4 cell count. Aids 21(13):1717-1721.

Pogany K, van Valkengoed IG, Prins JM, Nieuwkerk PT, van der Ende I, Kauffmann $\mathrm{RH}$, Kroon FP, Verbon A, Nievaard MF, Lange JM, Brinkman K. 2007. Effects of active treatment discontinuation in patients with a CD4+ T-cell nadir greater than 350 cells/mm3: 48-week Treatment Interruption in Early Starters Netherlands Study (TRIESTAN). J Acquir Immune Defic Syndr 44(4):395-400.

Poulton MB, Sabin CA, Fisher M. 2003. Immunological changes during treatment interruptions: risk factors and clinical sequelae. Aids 17(1):126-128.

Rouzioux C, Hubert JB, Burgard M, Deveau C, Goujard C, Bary M, Sereni D, Viard JP, Delfraissy JF, Meyer L. 2005. Early levels of HIV-1 DNA in peripheral blood mononuclear cells are predictive of disease progression independently of HIV-1 RNA levels and CD4+ T cell counts. J Infect Dis 192(1):46-55.

Ruiz L, Martinez-Picado J, Romeu J, Paredes R, Zayat MK, Marfil S, Negredo E, Sirera G, Tural C, Clotet B. 2000. Structured treatment interruption in chronically HIV-1 infected patients after long-term viral suppression. Aids 14(4):397-403.

Sarmati L, Andreoni C, Nicastri E, Tommasi C, Buonomini A, D'Ettorre G, Corpolongo A, Dori L, Montano M, Volpi A, Narciso P, Vullo V, Andreoni M. 2009. Prognostic factors of long-term CD4+count-guided interruption of antiretroviral treatment. J Med Virol 81(3):481-487.

Skiest DJ, Morrow P, Allen B, McKinsey J, Crosby C, Foster B, Hardy RD. 2004. It is safe to stop antiretroviral therapy in patients with preantiretroviral CD4 cell counts $>250$ cells/microL. J Acquir Immune Defic Syndr 37(3):1351-1357.

Skiest DJ, Su Z, Havlir DV, Robertson KR, Coombs RW, Cain P, Peterson T, Krambrink A, Jahed N, McMahon D, Margolis DM. 2007. Interruption of antiretroviral treatment in HIV-infected patients with preserved immune function 
is associated with a low rate of clinical progression: a prospective study by AIDS Clinical Trials Group 5170. J Infect Dis 195(10):1426-1436.

Solages A, Vita JA, Thornton DJ, Murray J, Heeren T, Craven DE, Horsburgh CR, Jr. 2006. Endothelial function in HIV-infected persons. Clin Infect Dis 42(9):13251332.

Strain MC, Gunthard HF, Havlir DV, Ignacio CC, Smith DM, Leigh-Brown AJ, Macaranas TR, Lam RY, Daly OA, Fischer M, Opravil M, Levine H, Bacheler L, Spina CA, Richman DD, Wong JK. 2003. Heterogeneous clearance rates of long-lived lymphocytes infected with HIV: intrinsic stability predicts lifelong persistence. Proc Natl Acad Sci U S A 100(8):4819-4824.

Tarwater PM, Parish M, Gallant JE. 2003. Prolonged treatment interruption after immunologic response to highly active antiretroviral therapy. Clin Infect Dis 37(11):1541-1548.

Tebas P, Henry K, Mondy K, Deeks S, Valdez H, Cohen C, Powderly WG. 2002. Effect of prolonged discontinuation of successful antiretroviral therapy on CD4+ T cell decline in human immunodeficiency virus-infected patients: implications for intermittent therapeutic strategies. J Infect Dis 186(6):851-854.

Tebas P, Henry WK, Matining R, Weng-Cherng D, Schmitz J, Valdez H, Jahed N, Myers L, Powderly WG, Katzenstein D. 2008. Metabolic and immune activation effects of treatment interruption in chronic HIV-1 infection: implications for cardiovascular risk. PLoS ONE 3(4):e2021.

Thiebaut R, Pellegrin I, Chene G, Viallard JF, Fleury H, Moreau JF, Pellegrin JL, Blanco P. 2005. Immunological markers after long-term treatment interruption in chronically HIV-1 infected patients with CD4 cell count above $400 \times 106$ cells/l. Aids 19(1):53-61.

Wit FW, Blanckenberg DH, Brinkman K, Prins JM, van der Ende ME, Schneider MM, Mulder JW, de Wolf F, Lange JM. 2005. Safety of long-term interruption of successful antiretroviral therapy: the ATHENA cohort study. Aids 19(3):345348.

Yeni P. 2008. Prise en charge médicale des personnes infectées par le VIH. Recommandations du groupe d'experts: Médecine-Sciences Flammarion. 
Men, n (\%)

73 (63\%)

Age (years), median (IQR)

$39(25-80)$

Transmission group, $\mathrm{n}(\%)$

Homo/bisexual men

$57(49 \%)$

Heterosexuals

$46(40 \%)$

Intravenous drug users

AIDS status, $n(\%)$

$9(8 \%)$

$3(3 \%)$

CD4 nadir (cells $/ \mathrm{mm}^{3}$ )

- median (IQR)

$381(341-490)$

- CD4 nadir $<300 / \mathrm{mm}^{3}$

$13(11 \%)$

CD4 cell count $/ \mathrm{mm}^{3}$ at inclusion, median (IQR)

$806(676-940)$

Pre-ART plasma HIV-RNA $\left(\log _{10}\right.$ copies $\left./ \mathrm{mL}\right)$, median (IQR)

$4.2(3.8-4.5)$

Plasma HIV-RNA < 400 copies/mL at inclusion, $n$ (\%)

$106(91 \%)$

HIV DNA ( $\log _{10}$ copies $/ 10^{6}$ PBMCs) at inclusion

- median (IQR)

$2.3(1.9-2.8)$

- HIV-DNA > $2.56 \log$

$38(33 \%)$

Duration of ART (years), median (IQR)

$5.3(4.2-6.1)$

Triple nucleoside-based regimen, $\mathrm{n}(\%)$

$39(34 \%)$

Double nucleoside-based regimen, $n(\%)$

$17(14 \%)$

Non nucleoside-based regimen, $\mathrm{n}(\%)$

$41(35 \%)$

Protease inhibitor-based regimen, $\mathrm{n}(\%)$

$18(16 \%)$

Non nucleoside/protease inhibitor combination

$1(1 \%)$ 
Table 2: Risk factors of reaching the criteria for treatment resumption in

9

10

11

12 Total

13

14 Age (year)

15 Gender

16

17

18

19

20 Duration of ART

21 Type of ART

22

23

24 Prior AIDS status

25 Pre-ART CD4 $(\log 2)^{s}$

26

27 Pre-ART CD4 cells/mm3

28

29

30

31 Pre-ART VL $(\log 10)^{\#}$

32

33

34

35

36

37

$38 \mathrm{CD} 4$ at inclusion cells $/ \mathrm{mm} 3$

39

40

41

42 CD4 nadir $(\log 2)^{\S}$

43

$44 \mathrm{CD} 4$ nadir cells/mm3

45

46

47

48 HIV DNA (log10) copies/million

49 PBMCs

50 HIV DNA $(\log 10)$

51

52

53

54 HIV DNA $(\log 10)>2.56$

univariate analysis and multivariable Cox proportional hazards models

Univariate analysis

Number of

(patients, events)

$(\mathrm{N}=116, \mathrm{n}=32)$

\begin{tabular}{|c|c|c|c|}
\hline & & $1.00(0.96-1.03)$ & 0.779 \\
\hline Women & $(\mathrm{N}=43, \mathrm{n}=12)$ & 1 (reference) & \\
\hline Men & $(\mathrm{N}=73, \mathrm{n}=20)$ & $0.99(0.48-2.08)$ & 0.966 \\
\hline No & $(\mathrm{N}=59, \mathrm{n}=16)$ & 1 & \\
\hline Yes & $(\mathrm{N}=57, \mathrm{n}=16)$ & $1.04(0.52-2.09)$ & 0.905 \\
\hline & & $0.96(0.76-1.21)$ & 0.709 \\
\hline $\begin{array}{l}\text { cART } \\
\text { dual therapy }\end{array}$ & $\begin{array}{l}(\mathrm{N}=99, \mathrm{n}=31) \\
(\mathrm{N}=17, \mathrm{n}=1)\end{array}$ & $\begin{array}{l}1 \\
0.17(0.02-1.27)\end{array}$ & 0.085 \\
\hline
\end{tabular}

$>519$

405-519

$<405$

$<10000$

$10000-27000$

$>27000$

$(\mathrm{N}=41, \mathrm{n}=9)$

$(\mathrm{N}=36, \mathrm{n}=9)$

$6.32(1.85-21.64)$

0.003

$7.14(1.43-33.33)$

0.017

0.116

$(\mathrm{N}=39, \mathrm{n}=8)$

$(\mathrm{N}=40, \mathrm{n}=10)$

$(\mathrm{N}=37, \mathrm{n}=14)$

1

$1.35(0.53-3.43) \quad 0.524$

$2.40(1.00-5.72) \quad 0.049$

$2.04(0.85-4.90)$

0.109

0.324

1

$(\mathrm{N}=36, \mathrm{n}=14)$

$1.35(0.53-3.40)$

$1.89(0.82-4.36)$

0.529

$3.03(0.93-10.10)$

0.065

0.035

$>885$

$700-885$

$<700$

$(\mathrm{N}=35, \mathrm{n}=7)$
$(\mathrm{N}=39, \mathrm{n}=8)$
$(\mathrm{N}=42, \mathrm{n}=17)$

$1.22(0.44-3.37) \quad 0.700$

$2.77(1.15-6.71) \quad 0.024$

$6.25(1.78-25.00)$

0.004

0.169

$(\mathrm{N}=38, \mathrm{n}=7)$

$(\mathrm{N}=40, \mathrm{n}=12)$

$(\mathrm{N}=38, \mathrm{n}=13)$

$361-448$

$<361$

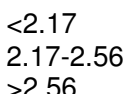

$2.17-2.56$
$>2.56$

$(\mathrm{N}=36, \mathrm{n}=6)$

$(\mathrm{N}=38, \mathrm{n}=17)$

$(\mathrm{N}=38, \mathrm{n}=17)$

$2.10(0.82-5.35)$

$2.35(0.94-5.89)$

0.120

0.069

$1.94(1.13-3.35) \quad 0.017$

0.031

$0.96(0.32-2.86) \quad 0.944$

$2.60(1.08-6.27) \quad 0.034$

$2.65(1.28-5.45)$

0.008
270.4

Multivariable analysis

0.007

272.8

271.7

272.4

273.6

270.3

$268.8 \quad 4.59(1.22-17.24) \quad 0.024$

273.0

251.9

250.8

$2.15(1.02-4.53)$

0.044

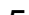

${ }^{\S}$ Hazard Ratio per two-fold decrease in the CD4 cell count; ${ }^{\#}$ Hazard Ratio per ten-fold increase in plasma

HIV-RNA; $N=$ number of patients; $n=$ number of events during follow-up; $A I C=A k a i k e ' s$ information criterion: used to select models (the best model has the lowest AIC). 
1

Hip circumference (cm), median (IQR)

Waist $(\mathrm{cm})$

Waist/hip ratio

Thigh circumference $(\mathrm{cm})$

Body mass index $\left(\mathrm{kg} / \mathrm{m}^{2}\right)$

Lipodystrophy score, median (IQR)

- $\quad$ atrophy $\geq 1, \mathrm{n}(\%)$

- $\quad$ hypertrophy $\geq 1, \mathrm{n}(\%)$

Total fasting cholesterol serum level (mmol/l), median (IQR)

Fasting HDL cholesterol serum level (mmol/l), median (IQR)

Fasting LDL cholesterol serum level (mmol/l), median (IQR)

Fasting triglyceride serum level ( $\mathrm{mmol} / \mathrm{l})$, median (IQR)

Fasting glucose serum level (mmol/l), median (IQR)

\section{Baseline}

\author{
Last values \\ during
}

interruption
$90.8(86.0-90.8) \quad 91.0(86.8-97.0) \quad 0.010$

$83.0(76.0-90.0) \quad 83.0(76.0-91.3) \quad 0.251$

$0.92(0.87-0.99) \quad 0.91(0.87-0.97) \quad 0.203$

$47.0(44.0-50.0) \quad 47.0(44.0-51.0) \quad 0.258$

$22.9(20.7-24.5) \quad 22.8(20.7-25.1) \quad 0.468$

$1.0(0.0-4.0) \quad 0.0(0.0-1.0) \quad<0.001$

$49(42 \%) \quad 25(23 \%) \quad<0.001$

$50(43 \%) \quad 18(16 \%) \quad<0.001$

$5.10(4.38-5.74) \quad 4.58(4.11-5.22) \quad<0.001$

$1.22(1.02-1.49) \quad 1.13(0.95-1.36) \quad<0.001$

$3.08(2.48-3.72) \quad 2.82(2.36-3.33) \quad 0.001$

$1.18(0.80-1.86) \quad 1.08(0.78-1.60) \quad 0.076$

$5.00(4.54-5.40) \quad 4.94(4.43-5.50)$

0.928 
Figure 1: Changes in the CD4 cell count (a) and plasma HIV-RNA (b) during treatment interruption and in PBMC HIV DNA during the first 18 months of treatment interruption (c)

Data points represent median values and whiskers represent interquartile ranges in (a) and (b). The dotted curve in (a) represents predicted changes in the CD4 cell count predicted by mixed linear models. The box plots in (c) represent median and interquartile ranges and whiskers indicate minimum and maximum values.

a

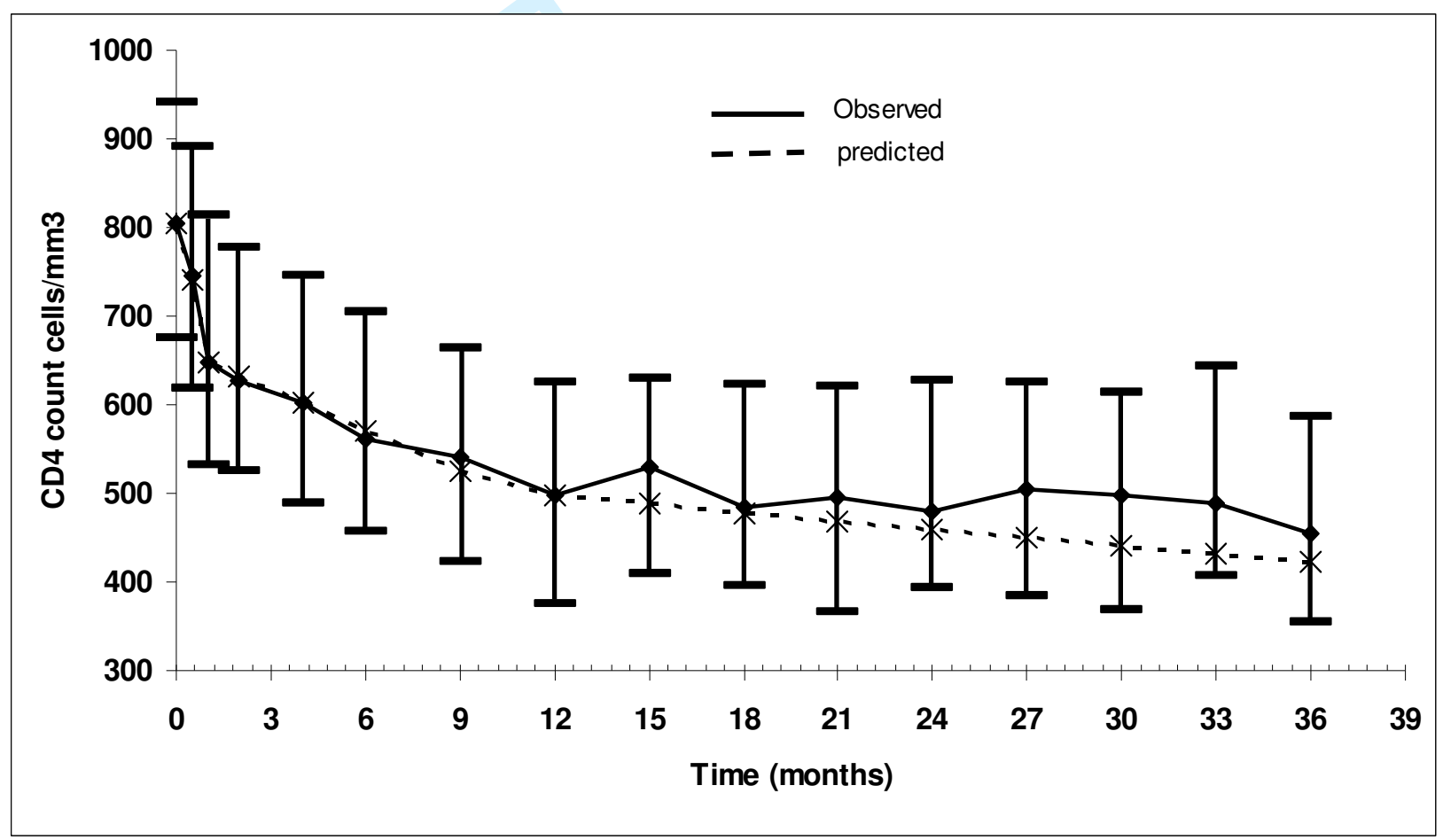


b

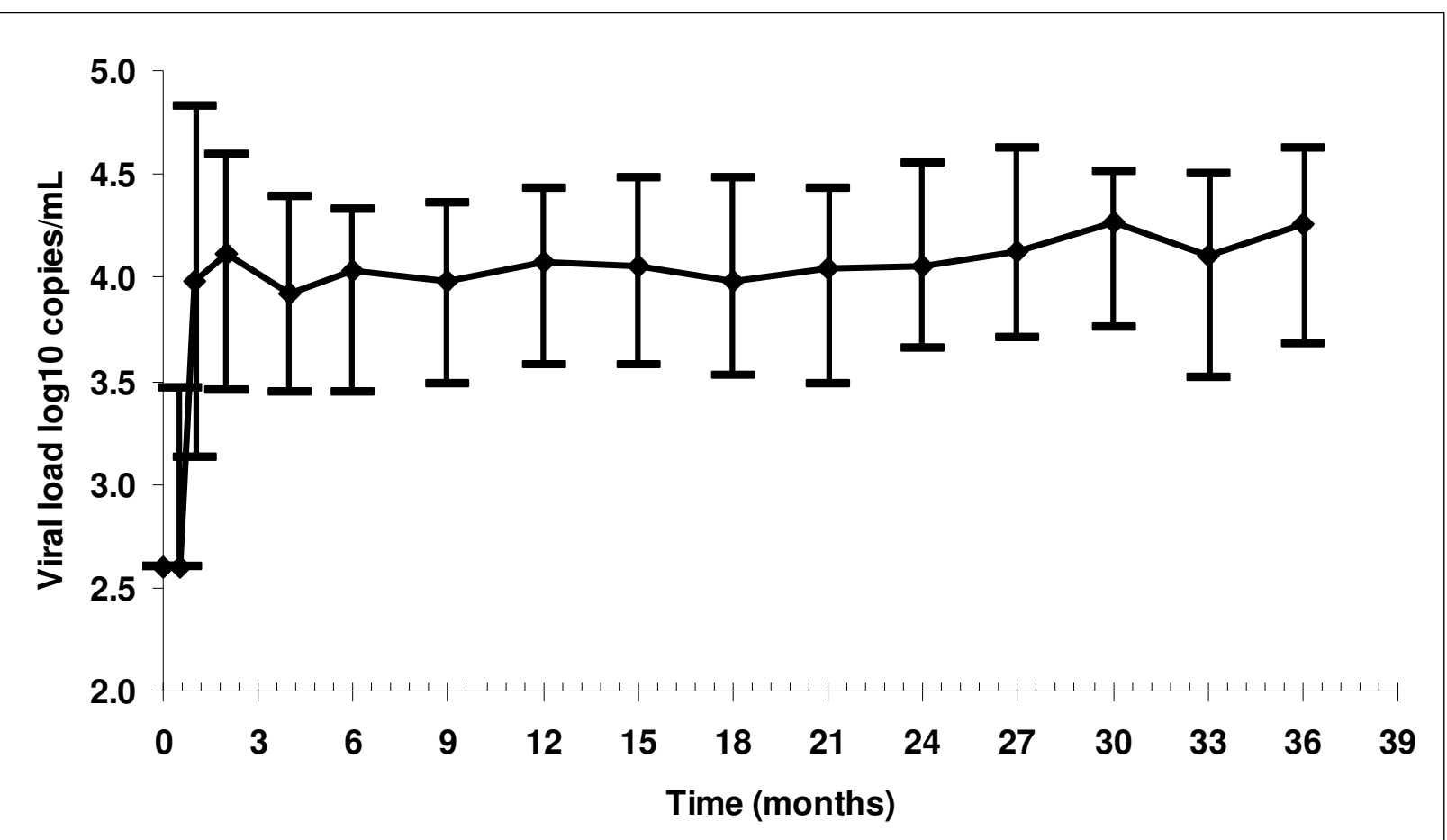


C

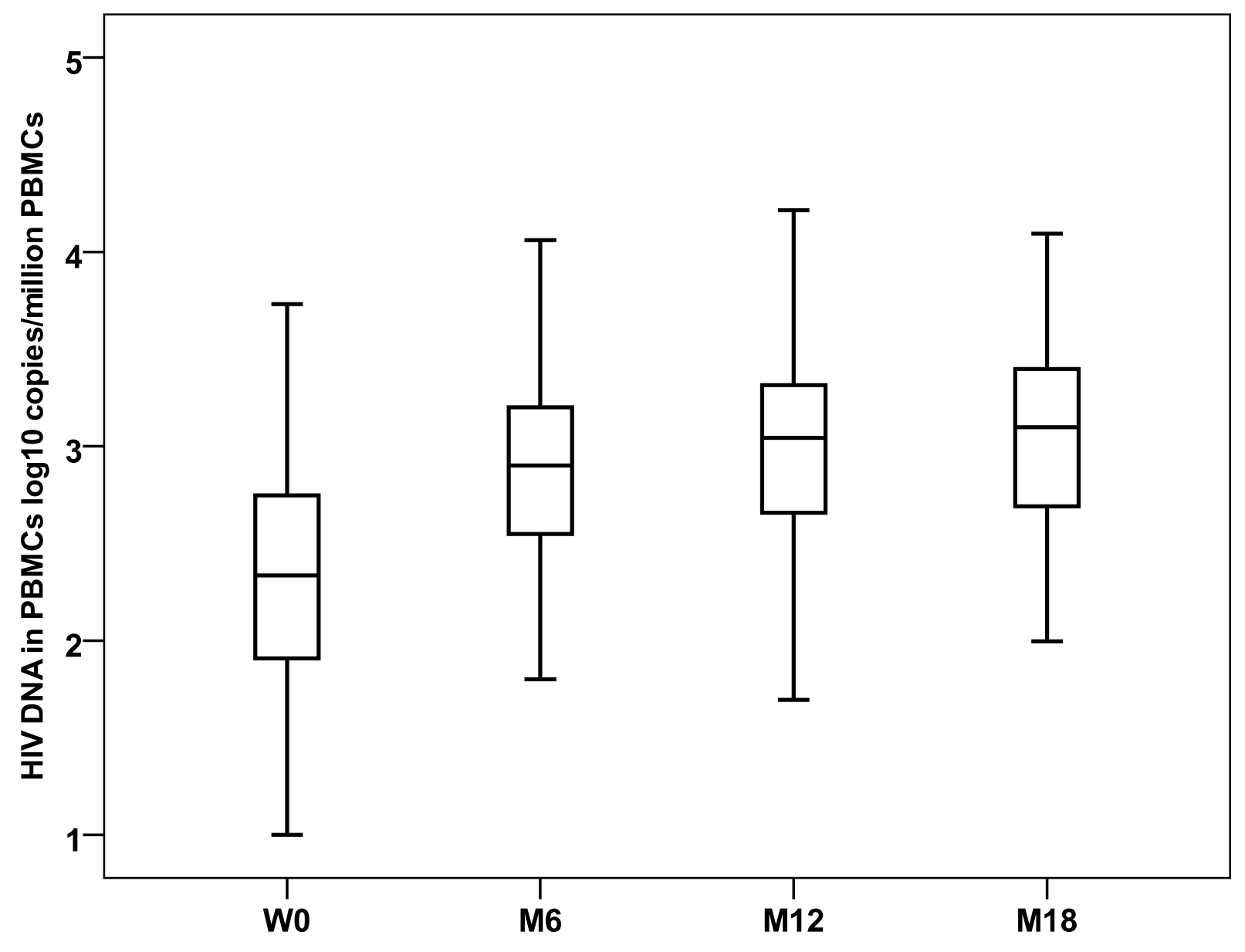


Figure 2: Kaplan-Meier curve of time to the endpoint according to the HIV DNA level adjusted for the CD4 cell nadir

The curves represent the time taken to reach the criteria for treatment resumption in patients with baseline HIV DNA load below and above 2.56 log copies $/ 10^{6}$ PBMCs (upper tercile).

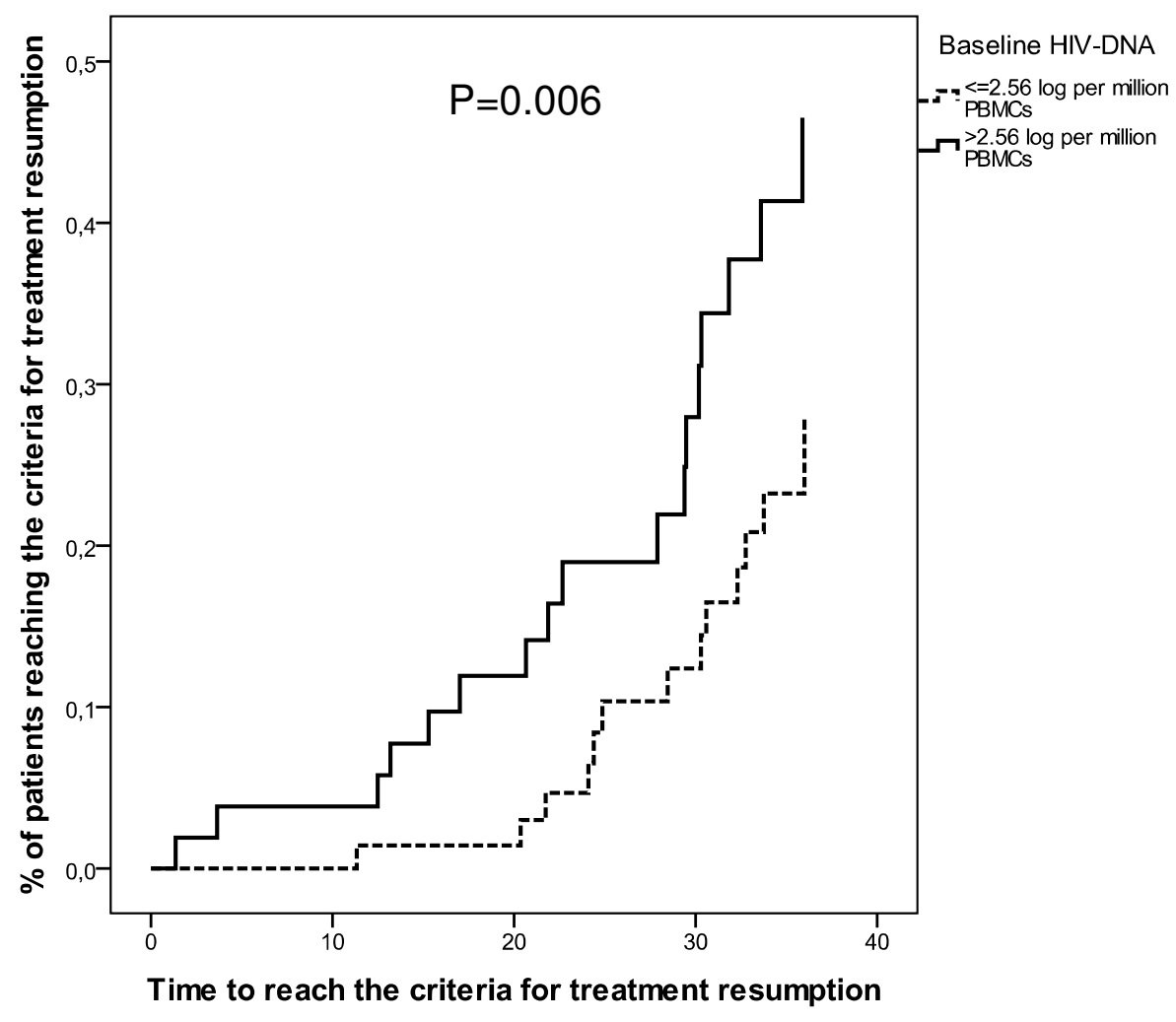

